\title{
A Portrait of Culture-Propelled Philanthropy: Ngadang Duren Activism in Maro Sebo Ilir, Jambi
}

\author{
$1^{\text {st }}$ Eja Armaz Hardi ${ }^{1}, 2^{\text {nd }}$ Efni Anita ${ }^{2}, 3^{\text {rd }}$ GWI Awal Habibah ${ }^{3}$ \\ \{eja.armaz.hardi@uinjambi.ac.id ${ }^{1}$, efniraffa@gmail.com², awalmadu@uinjambi.ac.id ${ }^{3}$ \}
}

UIN Sulthan Thaha Saifuddin Jambi ${ }^{1,2,3}$

\begin{abstract}
Philanthropy activism has become a fever in a plethora of social movements. In Indonesia, upper-middle-class society has taken a significant role to assist needy people. On the other hand, in the lower-middle-class society in Maro Sebo Ilir, Jambi accomplished culture-propelled philanthropy on fruit crops. The chosen fruit is durian fruit and known as ngadang duren. This article utilized in-depth interviews with a key informant and field observations of ngadang duren. It argued that ngadang duren has been conveyed for generations by the dweller in the Terusan village, Maro Sebo Ilir District. This article also asserted that Pesirah has simplified the religious teachings to obey the zakat, infaq, alms, and waqf commands to encourage the dweller in giving charity through their natural resources. Furthermore, it also argued that ngadang duren enriched the Islamic philanthropy discourses, particularly beyond the charity movement of state and non-state actors.
\end{abstract}

Keywords: Ngadang Duren, Islamic Philanthropy, Culture, Islamic Teaching, Collective alms

\section{Introduction}

In the middle of 2018, the car we were driving pulled over in the Maro Sebo Ilir sub-district, Batang Hari Regency for a short rest after approximately three hours of driving to Jambi city. During the stopover, a friendly chat at a coffee shop with residents brought us to the fascinating topic. The topic is unique charity activism. It has been done by the dweller of Terusan village, Maro Sebo Ilir District, Batanghari Regency, Jambi Province. In sum, the dweller of the Terusan village did not donate their money but with the planted natural resources. The plant is a durian fruit which is one of the fruits that has a distinctive taste and smell, also dubbed as the king fruit. Despite it, there are tremendous fans of durian fruit. Therefore, when the durian season arrives, durian is not only served as street food along the road but also one of the desserts for guests from outside of Jambi province. Interestingly, while urban people have to buy durian fruit on the roadside but for the Terusan's residents, the durian fruit has been utilized to articulate the values of charity in the Islamic teaching frameworks. The charity activity using durian fruit is known as ngadang duren.

The attention of scholars on the philanthropic movement, in general, has come to the initiation vibrancy of stoke holders through regulations to promote philanthropy [1]. The investigation in Islamic philanthropy has arrived at the discourse of beyond compassion, which has prevailed in the western world [2]. It has been confirmed in Resala's philanthropic volunteers in Egypt. Their voluntarisms are motivated by an impulse that goes beyond human 
motivations [3]. However, it was also found that the pulse that became the driving force of philanthropic activities was the commodification of religious symbols in attracting donations from the philanthropist's interest [4]. The impulse of the philanthropic movement separated the distinction among the currents of philanthropic activism, especially in Indonesia

The contemporary studies in Indonesian philanthropy are focused on three streams. Firstly, the mainstream is the formal philanthropic institution's movement, known as state actors. The formal philanthropic was born under government initiation. The goals and targets of the recipients have been well-programmed [5]. The program tends to be side by side with government poverty alleviation programs. Second, a study focuses on the generosity of private philanthropic activism, known as non-state actors. Private philanthropic institutions have the flexibility to innovate in targeting the beneficiaries [6][7]. Flexibility and innovation are conveyed by focusing on one of the core programs, such as economic [8][9], health [10][11], social empowerment [12][13], and based on the local wisdom of society [14]. Although, private philanthropic institutions still have an attachment to the policies set by the government through the National Amil Zakat Board (BAZNAS) as the regulator of the national charity activism [15]. The third is investigations beyond the two major currents of the philanthropic movement above, namely the philanthropic activism initiated by outsider activists from formal and private philanthropy institutions [16][17][18]. The third stream has become a new current in philanthropic activism in Indonesia. It disrupted the flow of the bureaucracy and the programs launched by the two previous streams.

\section{Methodology}

This article is focused on the third stream of philanthropic movement. The third stream has compassed without going through a planned program, flowing as it is, and directly providing the needs of beneficiaries. This article is distinguished on the object used to deliver the alms. Recently, the tool to manifest alms is cash. It was collected from donors and distributed to the beneficiaries in the form of necessities or cash [19]. This article is distinguished by the object of alms which is the durian fruit. So, at a settled time, people outside the village of Terusan are allowed to take the fallen durian fruit to take it away and consume it. This activism has been considered as alms and gratitude for the blessings they have received so far. Therefore, this article is purposed to analyze charity activism through durian fruit (ngadang duren) in Terusan village, Batanghari District. The in-depth interviews with stakeholders and field observation have been attempted in this article. This article argued that alms activities through ngadang duren were conveyed for generations from the ancestors of the dwellers of the Terusan village. Furthermore, there is a simplification of religious teachings about zakat, infaq, alms, and waqf delivered by Pesirah (religious leaders) in encouraging people to obey Islamic teachings. As a result, the people of the Terusan village have spiritual satisfaction through the ngadang duren procession as a form of embodiment of religious orders that oblige Muslims to share a piece of their property. To manifest their obedience and to receive God's blessing on their lives, they shared the harvested-durian on the tree. It is because the most feasible thing for Terusan's dwellers is to donate the durian fruit harvest. After all, at that time the durian fruit field had become a massive plant. This article argued that ngadang duren in Terusan village has enriched the discourse on philanthropy issues, especially in the third stream of charity activism in Indonesia. 


\section{Result and Discussion}

\subsection{Indonesian Philanhropy Activism}

Early after the toppling of the New Order Regime in the late 1990s, philanthropic institutions in Indonesia have had free space to accommodate social activities [20]. Those had exhibited by the massive births of various philanthropy institutions. The basis of post-New Order philanthropic institutions was born from the womb of different backgrounds, [21] such as media-based philanthropic institutions, Islamic religious organizations, independent organizations, corporations, and family-based philanthropy [18]. Along with the drivenvariations of the different forms of those, the philanthropic movement in Indonesia has heterogeneity in patterns, programs, and targets in channeling between donors and beneficiaries.

Contemporary philanthropy activism in Indonesia is divided into three core patterns, namely formal, non-formal, and cultural philanthropy. The formal-philanthropic institutions are initiated and formed by the government. Such as the National Amil Zakat Agency (BAZNAS) was born through law number 23 of 2011 about zakat. The law regulates the guidelines of BAZNAS in collecting, distributing, and empowering Zakat, Infaq, Alms, and Waqf (ZISWAF) funds. In taking responsibility for maintaining the national ZISWAF fund, BAZNAS has a planned program that has combined five major programs, namely economy, education, da'wah, health, and socio-religious. Each program receives different portions of funds. It is because the funding distribution in each program distributed belongs to a priority scale. Therefore, BAZNAS cannot immediately leap to innovate beyond the programs mentioned in the BAZNAS laws and regulations.

The strictness programs of the state actor have been innovated through non-formal philanthropic institutions. The non-formal philanthropic institutions referred to philanthropy institutions that are initiated and formed independently by religious organizations, corporations, or families [22]. Nevertheless, Non-formal philanthropic institutions continue to refer to and follow the roadmap mentioned in Law Number 23 of 2011 about Zakat.[15] However, nonformal philanthropic institutions have the flexibility to innovate in empowering ZISWAF funds. It is because non-formal philanthropic institutions can choose the focus and targets of the five BAZNAS programs. Such as philanthropy institutions that only focus on education, disaster resolution [23] and relief, economic empowerment, [13] and so on.

The regulations mentioned in Law Number 23 of 2011 and BAZNAS regulations contain complete guidelines for philanthropic institutions. These guidelines serve as a reference for formal and non-formal philanthropic institutions in carrying out their social activities. Critically, these guidelines have become a source of drawbacks faced by several philanthropy institutions. Besides the management, the formal philanthropy institutions addressed the problem of collecting funds from donors and distributing them to recipients. In addition, the lack of philanthropy institutions innovation in Indonesia became a source of anxiety as a driver to take a role through innovations in various fields. For example, innovations that cut the bureaucratic flow of philanthropic institutions have recently developed among young people.

Today, the third stream, outside the two formal and non-formal philanthropic activisms, has provided a new perspective in channeling donations to the beneficiaries. It has manifested in the charity activism of youth who are sensitive to contemporary social issues. It has been done by young students at the State Islamic University (UIN) through the student organization Griya Derma in Surabaya and Tangan Recehan in Jambi [18]. The two youth charity organizations have contributed to disrupting the bureaucratic flow of philanthropic institutions. They act as 
mediators who directly survey the beneficiaries candidate, find donors, and distribute the needs of goods or cash to recipients. In this case, recipients do effortlessly come to philanthropic institutions to get assistance, but they are visited directly by youth. In other words, the thirdstream bureaucratic distribution model is straightaway providing the finished goods, not programs. That is due to the urgent today needs of beneficiaries.

\subsection{Ngadang Duren in Terusan village, Maro Sebo Ilir District}

Maro Sebo Ilir District is the result of the expanding of Muara Bulian District and Pemayung District based on Batanghari District Regulation No. 02 of 2003. With a territorial area of about $303.98 \mathrm{sq} \mathrm{km}$, the Maro Sebo Ilir sub-district is divided into seven villages, two of them are Terusan village and Manau Embat village, which are determined in the Batanghari watershed (Daerah Aliran Sungai/DAS) [24]. The others are former Transmigration Settlement Units (UPT) which have a high and hilly terrain structure. Before following the hierarchical structure of the Indonesian administration, Maro Sebo Ilir adopted a mergo [25] government system led by a Pesirah. Pesirah had the authority to regulate several villages, and he had a significant role in the social and religious activities of the community at that time. Thus, the Pesirah fatwa can be the legal basis of activism in society.

One of the Pesirah' sustainable fatwas is giving alms with fruits that have been wellimplemented by the dweller in the village of Terusan. The model of giving alms fruits planted by the resident began in the 1920s, a Pesirah ordered the resident to deliver charity to the plants they had [26]. The choice of fruit plants aims to serve people who do not have fruit trees. Meanwhile, the fruits chosen at that time were durians which bear seasonal fruit. Based on the Pesirah order, the society is willing to donate their durian fruit to be taken by other people who do not have durian tree fruit.

The charity activity with durian fruit in the village of Terusan is known as 'ngadang duren'. Ngadang means blocking or waiting for the durian to fall from the tree. While duren in Indonesian means durian fruit, the meaning of ngadang duren is to assortment or wait for the durian fruit to fall from the tree [26]. People who participate in the ngadang duren activity are allowed to bring durian fruit home. Whatever amount they get during the ngadang duren procession is unpermissible to be resold but only for consumption. That is in line with the initial spirit of the Pesirah order in donating durian fruit to provide opportunities for people who do not have durian fruit plants to enjoy durian fruit. The outsider who participated in ngadang duren felt pleasure because the ngadang duren enable a strengthening of the families. Furthermore, the ngadang duren participants must prepare their provisions to pass the night while waiting for the falling durian, such as food, mosquito repellent, and flashlights.

People who are willing to enjoy durian fruit for free and experience assortment the durian from falling in the middle of a durian field can follow it at certain times [27]. Due to the consensus of the dweller of the Terusan village. Besides the ngadang duren held when the durian season arrives, the ngadang duren lasts approximately 13 hours, starting from Monday at around 05.00 p.m till 06.00 a.m on Tuesday [27]. Only marked trees that have been girted by a white scarf which allowed to take the fruits. It means that the trees without the mark are unpermissible to take the fruits [26]. The direct pattern of the ngadang duren to deliver durian to the beneficiary is similar to the flow of the third philanthropic activism beyond the formal and non-formal streams. In addition, the ngadang duren activity does not involve formal or nonformal philanthropy organizations. These activities are independent without the technical and regulatory requirements as in philanthropic institutions. 
Participants who took part in the ngadang duren procession came from various regions. Some are from the Batanghari district, and some are from outside, such as Jambi city, Sarolangun and others. The visitors have a different background. Some visitors work as state civil servants, and some are private sector. From direct interviews with visitors, they admitted that they wanted to participate in the ngadang duren procession because they got durian for free. Some of them invite their families to spend the night together. The excitement of enjoying the night while waiting for falling durian directly from the tree has its pleasure for visitors. In addition, they also build communication between families and other visitors while waiting for falling durian. So, indirectly a sense of brotherhood is present in their midst.

From the perspective of the durian owner, the one who donates his durian fruit to the ngadang duren procession does not see who is coming. The visitors come from the have and who are not. They thought that by giving alms with the durian, they felt satisfied. They were happy when they saw the people enjoying the durian that had just fallen from the tree. Although the spirit of Islamic generosity required the specific recipients of alms, the necessary thing for durian owners is how to keep sustainable sharing to others. For them, people who do not have durian fruit are a group that deserves to enjoy the alms they serve.

\section{Pesirah role}

The direct distribution of durian fruit was aptitude by the initial spirit of the Pesirah order inviting the community to have a great attitude and love to share. The Pesirah preaching ordered the Terusan dweller to share the fruit due at that time still adhered to the mergo system. It was one of the reliable ways and facilitated understanding of the implementation of religion for the community. It is not surprising because the beginning of Islamic preaching conveyed by the foremost ulama in Indonesia also used identical methods to facilitate public understanding of Islamic teachings. Dakwah and invitations have proven successful through the simple term to manifest religious teachings in everyday life. Due to installing religious values for uneducated people about Islamic teachings needs simpler preaching.

From the Islamic philanthropy perspective, the concept of sustainable ngadang duren in Terusan Village is more like the concept of alms in Islam. The alms concept in Islam does not require binding conditions such as zakat. In zakat, the object of zakat has to reach a peak of nisab, haul, and the percentage. Besides, in almsgiving, specific terms do not require. The alms in Islamic teachings have been stated comprehensively in surah al-Baqarah (2:261), [28] which mentions the reward and how a Muslim should share his wealth. The bounties given by Allah to a Muslim who sets aside his wealth through charity are counted 700 times [28]. In addition to the 700-fold reward, Islam suggests unfollowing the alms with actions that hurt the recipient. Therefore, the sincerity of the donor in donating his property is necessary. Due to it is to get the blessings of sustenance and rewards that have been promised in the Qur'an.

The union of the dweller spiritual experience in Terusan village has brought sustainable ngadang duren activism. This spiritual experience is esteemed by several residents who make their durian fields the object of ngadang duren. During donation in the harvest days of durian fruit, especially on Tuesday night until tomorrow they felt invaluable satisfaction. That satisfaction came from a manifestation of religious [29] orders to give alms. Furthermore, they felt pleased to see other people enjoying the harvest. The satisfaction of the dweller in Terusan village in manifesting religious orders through the ngadang duren activism was in line with Mettimayer's findings at the Resala in Egypt, namely being kind to others in the name of religion. Not only getting a spiritual experience from the annual ngadang duren activism but also the amount of harvest they get tends to be higher than the trees that are un-used as the object 
for ngadang duren. The increase in the harvest will directly provide additional income for the Terusan dweller. Even some of the people feel the promise of multiplied rewards mentioned in the Qur'an.

Based on the discourses mentioned above, it is shown that charity activism in the Maro Sebo Ilir dweller enriches the treasures of the third philanthropy movement, namely the administrative uninvolved philanthropic. The absence of philanthropy organizations in $n$ gadang duren does not mean to express public distrust of philanthropy institutions in Indonesia.[30] Like what has been done in several youths' philanthropic activities that disrupted the administration. But more to the technical matter of object distribution of charity that is donated. Since it has been running for a century, so the dweller agreed to hold the ngadang duren as it is.

The absence of philanthropic institutions in ngadang duren activities revealed implicit criticism and sustainable local wisdom in the grass-root societies. Although ngadang duren was born early than the third contemporary philanthropic movement, both reduced the role of the bureaucracy of philanthropy institutions. As a result, it emphasized the lack of public trust in distributing alms through philanthropy institutions. Even some donors prefer to channel their charity to the chosen recipients directly [31]. On the other hand, ngadang duren has become a part of the life of the people of the Terusan Village in carrying out religious orders, especially giving alms.

However, the following distinction of ngadang duren activism in Terusan along the third stream philanthropy is the dweller does not promote ngadang duren through social media. As was done by Tangan Recehan, Griya Derma, [18] and Sedekah Rombongan, [16] who is aggressively promoting its movement. Both of them utilize various social media platforms to engage donors and annual public reports. But the ngadang duren activism tends to run well and sustainably because of lips promotion from the people who have experienced it. The command of the Pesirah became one of the core impulses of the ngadang duren activism. The Pesirah order called the margo's policy at that time. In Bornstein's view, both government regulations and efforts are the impulses of the philanthropic movement [1]. 


\section{Conclusion}

The wisdom preacher to simplifying religious teachings is necessary to encourage people in implementing the Islamic order. Ngadang Duren is a form of internalization of religious orders in inviting residents to give alms. Alms through the ngadang duren activity in the village of Terusan is a philanthropic movement that accommodates social landscapes so that religious teachings are well received. Because of the simplification of religious orders, the dweller coherently feels the impact of implementing ngadang duren between spiritual and worldly satisfaction. That makes the ngadang duren activity in the village of Terusan carried out over a long period and has been conveyed for generations. In addition, the model of alms that uses durian fruit has enriched the treasures of the Islamic philanthropic movement in Indonesia, especially in philanthropy that does not involve state or non-state institutions.

The disclosure of the ngadang duren activity in the village of Terusan proves that the strong sense of sharing between the middle and lower classes. This power is presented through adherence to religious teachings. Obedience in carrying out religious orders, especially charity which does not have to be with money but can use what is owned. Although the ngadang duren activity does not target recipients from the poor, it substantively reflects the generosity of Islam. Share the best you have for others.

Acknowledgments. There is no conflict of interest of the authors in the contents of this article.

\section{References}

[1] E. Bornstein, "The Impluse of Philanthropy," Cultural Anthropology, vol. 24, no. 4, pp. 622-651, Nov. 2009, doi: 10.1111/j.1548-1360.2009.01042.x.

[2] H. Cunningham, "The multi-layered history of Western philanthropy," The Routledge companion to philanthropy, no. Query date: 2021-03-08 09:17:41, 2016.

[3] A. Mittermaier, "Beyond Compassion: Islamic Voluntarism in Egypt," American Ethnologist, vol. 41, no. 3, pp. 518-531, Aug. 2014, doi: 10.1111/amet.12092.

[4] C. Tuğal, "Contesting Benevolence: Market Orientations among Muslim Aid Providers in Egypt," Qual Sociol, vol. 36, no. 2, pp. 141-159, Jun. 2013, doi: 10.1007/s11133-013-9248-6.

[5] K. Hassaian and A. Elrahman Elzahi Saaid, "Zakah for Poverty Alleviation: Evidance from Sudan," International Research Journal of Finance and Ekonomics, vol. 154, pp. 83-103, Oct. 2016.

[6] H. Latief, "Contesting Almsgiving in Post-New Order Indonesia," The American Journal of Islamic Social Sciences, vol. 31, no. 1, Art. no. 1, 2014.

[7] H. Latief, "Islamic Philanthropy and The Private Sector in Indonesia," Indonesian Journal of Islam and Muslim Societies, vol. 3, no. 2, pp. 175-201, 2013.

[8] S. Zalikha, "Pendistribusian Zakat Produktif dalam Perspektif Islam," Islam Futura, vol. 15, no. 2, pp. 304-319, 2016.

[9] A. Sarea, "Zakat as a Benchmark to Evaluate Economic Growth: An Alternative Approach," International Journal of Business and Social Science, vol. 3, no. 18, pp. 242-245, 2012.

[10] Z. Lessy, "Philanthropic Zakat for Empowering Indonesia's Poor: A Qualitative Study of Recipient Experiences at Rumah Zakat," Ph. D Thesis, Indiana University, Indianapolis, 2014. Accessed: Dec. 03, 2020. [Online]. Available: https://scholarworks.iupui.edu/handle/1805/4038 
[11] Z. Lessy, M. Adamek, and K. Khaja, "Philanthropic Zakat for the Disadvantaged: Recipient Perspectives from Indonesia," Asian. Soc. Work. Pol. Rev., vol. 14, no. 3, pp. 138-147, Oct. 2020, doi: 10.1111/aswp.12204.

[12] I. Asep - Suryanto (Universitas Siliwangi, I. Biki Zulfikri Rahmat (Universitas Siliwangi, and I. Lina Marlina (Universitas Siliwangi, "Islamic Philanthropy: Waqf Empowerment of Madina Minimarket In Tasikmalaya - Indonesia," IKONOMIKA, vol. 5, no. 2, Art. no. 2, May 2020, doi: 10.24042/febi.v5i2.5315.

[13] A. Suryanto, B. Rahmat, and L. Marlina, "Islamic Philanthropy : Waqf Empowerment of Madina Minimarket In Tasikmalaya -Indonesia,” vol. 5, pp. 1-16, May 2020, doi: 10.24042/febi.v5i2.5315.

[14] P. Suharso, S. Sarbini, and D. Sumarsono, "The Philanthropy Culture in the Local Area: The Role Study of Philanthropy Institution after the Termination of PNPM in Boyolali Regency," E3S Web Conf., vol. 68, p. 01012, 2018, doi: 10.1051/e3sconf/20186801012.

[15] R. Indonesia, Undang-Undang Republik Indonesia: Nomor 23 tahun 2011 tentang Pengelolaan Zakat, vol. 23. 2011.

[16] N. Kailani and M. Slama, "Accelerating Islamic Charities in Indonesia: Zakat, Sedekah and the Immediacy of Social Media," South East Asia Research, vol. 28, no. 1, pp. 70-86, Jan. 2020, doi: 10.1080/0967828X.2019.1691939.

[17] N. Kailani, "Forum Lingkar Pena and Muslim youth in contemporary Indonesia," Review of Indonesian and Malaysian Affairs, vol. 46, no. 1, pp. 33-53, Jan. 2012.

[18] E. A. Hardi, "Muslim Youth and Philanthropic Activism: The Case of Tangan Recehan and Griya Derma," epis, vol. 16, no. 01, pp. 15-29, Apr. 2021, doi: 10.21274/epis.2021.16.01.15-29.

[19] M. D. Rahmatya and M. F. Wicaksono, "Model of Receipt and Distribution of Zakat Funds Information System," in IOP Conference Series: Materials Science and Engineering, Sep. 2018, vol. 407, p. 012071. doi: 10.1088/1757-899X/407/1/012071.

[20] A. Fauzia, "Islamic Philanthropy in Indonesia: Modernization, Islamization, and Social Justice," Austrian Journal of South-East Asian Studies, vol. 10, no. 2, Art. no. 2, Dec. 2017, doi: 10.14764/10.ASEAS-2017.2-6.

[21] H. Latief, "Philanthropy and 'Muslim citizenship' in post-Suharto Indonesia," Southeast Asian Studies, vol. 5, no. 2, pp. 269-286, 2016.

[22] "Direktori Filantropi Indonesia - Memupuk Kedermawanan Menuai Kemandirian," 2020. https://filantropi.or.id/direktori/ (accessed Oct. 29, 2020).

[23] H. Latief, "Islamic Charities and Dakwah Movement in a Muslim Minority Island: The Experience of Niasan Muslims," Journal of Indonesian Islam, vol. 6, no. 2, pp. 221-44, 2014.

[24] B. P. S. Kabupaten Batanghari, "Badan Pusat Statistik Kabupaten Batang Hari, 'Kecamatan Maro Sebo Ilir Dalam Angka 2017,' Katalog BPS: 1102001.1504.042,” 2017.

[25] "Bahasa Indonesia 'Marga' yaitu 1. n Antr bagian daerah (sekumpulan dusun) yang agak luas (di Sumatera Selatan).," KBBI V Daring. Badan Pengembangan dan Pembinaan Bahasa, Kementerian Pendidikan, Kebudayaan, Riset, dan Teknologi Republik Indonesia, Jakarta, 2016.

[26] F. Abdi, "Interview-Chief of Custom Institution of Batanghari,” Jul. 2018.

[27] “Observation-ngadang duren processing," Sep. 2018.

[28] T. S. Al-Qur'an, Syamil Quran Hijaz: Terjemah Tafsir per Kata. Bandung: Sygma Creative Media Group, 2010.

[29] M. Atia, “'A Way to Paradise': Pious Neoliberalism, Islam, and Faith-Based Development," Annals of the Association of American Geographers, vol. 102, no. 4, pp. 808-827, Jul. 2012, doi: 10.1080/00045608.2011.627046. 
[30] L. Hamdani, M. Y. Nasution, and M. Marpaung, "Solusi Permasalahan Perzakatan di BAZNAS dengan Metode ANP: Studi tentang Implementasi Zakat Core Principles," muqtasid, vol. 10, no. 1, p. 40, Aug. 2019, doi: 10.18326/muqtasid.v10i1.40-56.

[31] N. Febrianti, "The Review of Islamic Law on the Distribution of Zakat Directly by Muzaki to Mustahik in the Sunan Ampel Religious Tourism Area in Surabaya," Iqtishaduna: Jurnal Ekonomi \& Keuangan Islam, vol. 11, no. 2, 2020. 